\title{
The Constitution of Nepal: On the Touchstone of Constitutionalism and Good Governance
}

\author{
Kapilmani Dahal
}

\begin{abstract}
Various types of constitutions can be seen in practice all over the world. However democratic constitution must have guaranteed the constitutionalism and good governance. In Nepal, the constitution is under the observed course. It can be tested on the touchstone of constitutionalism and good governance. The objectives of this article are: to describe the provisions relating to good governance and constitutionalism, to find out the relation between constitutionalism and good governance and to show the variables constitutionalism and good governance as essence of democracy. Descriptive-analytical methodology has been adopted in the process of writing. Qualitative information has been taken from the constitution of Nepal. The constitution of Nepal has adopted some attributes of constitutionalism and good governance. The constitution is in the process of implementation so what types of indicators it will show; it has become the subject of positive expectation for all the people. Constitutionalism and good governance are not only the basic elements of democracy but also the essence of democracy and they are interrelated also. So the constitution will be successful when it will provide the constitutionalism and good governance properly in practice.
\end{abstract}

Keywords: Constitution, constitutionalism, democracy, good governance, power, rule. 


\section{Background}

Constitution is the fundamental law of the land. It is called supreme law, highest law, legal document and political document. Right and responsibility are given to people in the constitution. It is the blueprint, guideline, road map or directive for governance system. Constitution is made on the basis of social contract theory. It is the reflection of general will of the people. Democratic constitution is made to end arbitrary rule and for limited government. On the other hand, it is the proof of political agreement concluded between the rulers and the ruled.

The base and source of democracy is the constitution. Democratic constitution can only protect the democracy. The word 'democracy' has become common terminology in the politics. In the word of Abraham Lincon, democracy is the form of government of the people, by the people and for the people. We can get various definitions of democracy. However it is the form of governance empowering people in the society. The ruler can gain the political power from the people. In democracy, people rules over themselves. Ruling power is vested in the hands of the people in the community. It is the government of the best, wisest for progress and prosperity of all and through all. Every people can claim the share in democratic polity. All popular governance is supposed democratic governance. Ruling people can't only see but also feel the implementation of right share in the exercise of sovereign power in the democratic system.

Power of state remains at the hands of people and people become source of state in democracy. Representatives of majority govern but they safeguard the interest of minority people in the plural society in the democratic system. The meaning of democracy varies according to the governance system. The communist rulers deny the need of government and they give 
focus on democratic state. A democratic state to them is only a socialist state in which there should be the dictatorship of the proletariat. They oppose of the western form of democracy. the communist state and government cannot be democratic state and democratic government. Multi-party system and pluralism is the backbone of democracy but one party dictatorship is basic feature of communist system. Democracy is the responsible rule and system. It argues that the source of state is people. So sovereignty must be vested in the people.

Democracy has various essential elements. They can be enumerated as: rule of law, separation of power, pluralism, decentralization of powers, division of power, periodic election, multiparty system, existence of civil society, autonomous media and public sphere, civic participant political culture, good governance, constitutionalism, human rights, fundamental rights, independent judiciary, adult franchise, etc. but constitutionalism and good governance are the basic essence of democracy.

\section{Objectives to the study}

The objectives of this study are as follow:

1. To show or describe the provisions made in the constitution of Nepal about good governance and constitutionalism.

2. To analyze the relationship of good governance and constitutionalism,

3. To find out or explore the variables-good governance and constitutionalism as the essence of democracy.

\section{Methodology}

Methods in political science vary according to characteristics of subject matter of study. This article has been written to focus on constitution of Nepal. Good governance and constitutionalism are 
main concerns of this study. The concept and principles are taken from various books or previous contributions and constitution of Nepal has studied on the touch-stone of good governance and constitutionalism. Descriptive-analytical study design has been applied. Data has been taken from the constitution of Nepal, so it is the universe of the study. Secondary information and library method has been applied in this qualitative study.

\section{The Constitution of Nepal}

According to Dicey- the constitution directly or indirectly affects the exercise of the sovereign power of the state (Diecy, 1948: 23). Political constitution is the branch of political science (Strong, 1966:364). Nepal has no long history of constitutional development. The Government of Nepal Act- 2004 BS was the first constitution of Nepal. It was promulgated by then Rana Prime Minister Padma Samser on $13^{\text {th }}$ of Marga. Namely it was act not constitution but in constitutional history it has been registered as constitution. It was never implemented. Rana were not happy to promulgate the constitution and they didn't want to give right to people. Then Nepal got other six constitutions but they could not run more than ten years in average. We have got lastly the Constitution of Nepal (2072). This constitution has promulgated by collective efforts of Nepalese people and constituent assembly. Basic features of the constitution are as follows:

Sovereign and state power vested in people, federal democratic system of government, three tiers of governance system, constitutional president elected by federal and provincial parliament, prime minister as executive head of the government, parliament cannot be dissolved within two years, and vote of no confidence cannot be registered against prime minister for two years. Constitution can be amended by two third majority 
of parliament, acceptance of role of provinces in the process of amendment of constitution, mixed electoral system, bi cameral legislature at the centre, minister in center no to be more than 25 members including prime minister, unilateral parliament in provincial parliament, provision of chief minister and provincial chief in province, number of provincial minister no to be more than twenty percent of total numbers of provincial parliament, mixed electoral system must be applied in the provinces, two third majority of the provincial parliament shall name the province, division of powers in the constitution in various schedule, unified integrated judiciary, secular state, citizenship by name of father and mother, separation of powers, protection of all languages, constitutional assembly can be transformed to parliament, increasing the number in fundamental rights of people, independent judiciary, constitutional organs, various commissions etc.

\section{Constitutionalism}

Constitutionalism is a principle added together to the constitution. The term constitutionalism is concerned with democracy. Constitutionalism cannot be seen there, where democracy hasn't been applied. Constitutionalism always stands for limited government. Division of power is basis of civilized government which is basic foundation of constitutionalism. Constitutionalism covers a significant place in comparative study of politics. The significance of constitutions of concerned country or of other countries can be studied standing on the foundation of principle of constitutionalism. Constitutionalism is possible in only democratic state not in totalitarian state. Rule of law is another name of constitutionalism. The basic assumption of constitutionalism is no man can be against the law, outside the law and above the law. The ruler and the ruled all 
should obey the rules and regulations. The reflection of general will can be seen only in constitutionalism. End of tyrannical regime and operating of democratic regime is the essence of constitutionalism. It stands for the supremacy of law and not of the individuals; it imbibes the principles of nationalism, democracy and limited government. It may be identified with the system of divided power (Friederich, 1964:25). Friederich further mentions that constitutionalism by dividing power provides a system of effective restraints upon governmental action. It is the body of rules ensuring fair play, thus rendering the government responsible (Ibid: 26). Constitutionalism stands for the existence of a constitution in a state. It is the instrument of government, or the fundamental law of the land, whose objects are to limit the arbitrary action of the government, to guarantee the rights of the governed, and to define the operation of the sovereign power (Wheare, 1956: 1).

\section{Varying concepts of constitutionalism}

Constitutionalism stands for a system having division of powers and an arrangement of checks and balances so that the government remains responsible; it also desires that the system be provided with adequate techniques and procedures that can bring about a systematic and orderly change (johari, 1998:269). It stands for against of abuse of power and centralization of power. Generally there are two types of concepts of constitutionalism; Fascist or communist concept of constitutionalism and democratic concept of constitutionalism.

The differences between them can be shown as follow.

\begin{tabular}{|l|l|l|}
\hline SN & Democratic concept & \multicolumn{1}{c|}{ Communist concept } \\
\hline 1 & $\begin{array}{l}\text { Constitution is supposed both } \\
\text { ends and means }\end{array}$ & $\begin{array}{l}\text { Constitution is supposed as means } \\
\text { only }\end{array}$ \\
\hline
\end{tabular}




\begin{tabular}{|c|c|c|}
\hline 2 & $\begin{array}{l}\text { Constitution as value free and } \\
\text { value laden document }\end{array}$ & $\begin{array}{l}\text { Constitution as value laden } \\
\text { document only }\end{array}$ \\
\hline 3 & $\begin{array}{l}\text { Constitution have empirical and } \\
\text { normative dimensions }\end{array}$ & $\begin{array}{l}\text { Constitution has only normative } \\
\text { dimension }\end{array}$ \\
\hline 4 & $\begin{array}{l}\text { Constitution accepts the norms } \\
\text { and values of democracy }\end{array}$ & $\begin{array}{l}\text { Constitution accepts the norms } \\
\text { and values of communism }\end{array}$ \\
\hline 5 & $\begin{array}{l}\text { Focus on democratic state and } \\
\text { limited government }\end{array}$ & $\begin{array}{l}\text { Focus on communist state and } \\
\text { unlimited government }\end{array}$ \\
\hline 6 & $\begin{array}{l}\text { More emphasis given on liberty } \\
\text { and equality }\end{array}$ & $\begin{array}{l}\text { Emphasis given on named } \\
\text { equality only }\end{array}$ \\
\hline 7 & $\begin{array}{l}\text { Media and civil society as fourth } \\
\text { estate of government }\end{array}$ & $\begin{array}{l}\text { Media and civil society as } \\
\text { subordinate part of government }\end{array}$ \\
\hline 8 & $\begin{array}{l}\text { State based on democratic } \\
\text { socialism }\end{array}$ & $\begin{array}{l}\text { State based on communist } \\
\text { socialism }\end{array}$ \\
\hline 9 & $\begin{array}{l}\text { Constitution made on the basis of } \\
\text { custom, convention, democracy, justice } \\
\text { and other constitutional sources }\end{array}$ & $\begin{array}{l}\text { Constitution made on the basis of } \\
\text { communist ideology }\end{array}$ \\
\hline 10 & $\begin{array}{l}\text { Emphasis on all peoples State/ } \\
\text { nation state }\end{array}$ & $\mathrm{E}$ \\
\hline 11 & Supremacy of constitution & ist party \\
\hline 12 & Multi party system & One party dictatorship \\
\hline 13 & $\begin{array}{l}\text { Laws made on the basis of } \\
\text { democratic principles }\end{array}$ & $\begin{array}{l}\text { Laws made on the basis of } \\
\text { communist ideology }\end{array}$ \\
\hline 14 & $\begin{array}{l}\text { Division or decentralization of } \\
\text { powers }\end{array}$ & $\begin{array}{l}\text { Un division or centralization of } \\
\text { powers }\end{array}$ \\
\hline 15 & $\begin{array}{l}\text { Emphasis given to guarantee of } \\
\text { fundamental rights of people }\end{array}$ & $\begin{array}{l}\text { Emphasis given to fundamental } \\
\text { duties of people }\end{array}$ \\
\hline
\end{tabular}

\section{Good Governance}

Good governance is the concept linked with participatory democracy. On the other hand, good governance is form of governance which is directly attached with participatory 
governance system. Governance is a system of shaping, distribution and exercise of political powers mainly. It is inevitable for management of nation's public affairs. Goals are national security, law and order, public good and service at minimum cost, public voice, civil participation, production, binding decision (Dahal, 2010:1-2). The attributes of good governance are: consensus orientation, transparency, rule of law, responsiveness, participation, accountability, equity and inclusiveness, effective and efficiency (UNDP: 1995; FES, 2007:22-23). Other attributes of good governance are: political accountability and legitimacy, a fair and reliable judicial system, bureaucratic accountability, freedom of information and expression, effective and efficient public sector management and co-operation with civil society organizations. Good governance is art of governance pertaining allocation of values and use of power given to concern authority. It is ideal which is difficult to achieve in totality. It is adopted to make democracy a people oriented. Media plays the important role for promoting good governance (Dahal, 2072:12). Good governance is also associated with encouragement of participatory democracy, leadership, civil society and decentralization of powers to the grass roots (Dahal, 1999: 96).

\section{Governance system under the Constitution of Nepal}

Nepal has no long history of constitution making. Although seven constitutions have been made and six constitutions have been implemented since 2004 to 2072 BS. Among these, the constitution of Nepal (2072) is currently implementing constitution. Politically, there have been managed there tires of governance; federal governance, provincial governance and local governance system. The fundamental characteristic of this constitution is division of powers but not decentralization of 
powers. This constitution has applied the model of governance ensuring efficiency in a democratic framework. Multi level governance system has been guaranteed in this constitution. Preamble is the spirit and essence of constitution and governance systems have been included in it.

This constitution has promulgated for ending all forms of discrimination and oppression created by the feudalistic, autocratic, centralized, unitary system of governance. Such as it has mentioned in the constitution that being committed to socialism based on democratic norms and values including the people's competitive multiparty democratic system of governance, civil liberties, fundamental rights, human rights, adult franchise, periodic elections, full freedom of the press, and independent, impartial and competent judiciary and concept of the rule of law, and build a prosperous nation.

To hereby pass and promulgate this constitution, through the constituent assembly, in order to fulfill the aspirations for sustainable peace, good governance, development and prosperity through the federal, democratic, republican, system of governance (preamble of constitution). Nepal is an independent, indivisible, sovereign, secular, inclusive, democratic, socialismoriented, federal democratic republican state (article 4). Both the sovereignty and state authority of Nepal has vested in the Nepalese people (article 2).

Provisions made under part 5, structure of state and distribution of state power is directly related to governance system. The main structure of the federal democratic republic of Nepal shall be of three levels, namely the federation, the state and the local level. The federation, state and local levels shall exercise the power of state of Nepal pursuant to constitution and law. There shall be three tiers of local level, they are: village institution, 
municipality and district assemblies. There are provisions of special, protected and autonomous reign. The federation, state and local levels should protect democratic republican federal system of governance. The powers of the federation have been enumerated in schedule 5 , such as state powers are enumerated in schedule 6 , concurrent powers of federation and state are enumerated in schedule 7 , local powers in schedule 8 and concurrent powers of the federation, state and local levels are enumerated in schedule 9. Residuary powers are vested in federation. Federation, state and local levels can do exercise of financial powers. The federation, state and local level may impose taxes on matters falling within their respective jurisdiction and collect revenue from these sources. There are provisions for equitable distribution of the collected revenue to all levels of government. The form of government of Nepal shall be multi-party, competitive, federal, democratic, republican, parliamentary form of government based on pluralism. There are also provisions relating to state government.

\section{Constitutionalism and the Constitution}

Constitutionalism is the concept connected with the constitution. Political constitutionalism, legal constitutionalism, sociocultural constitutionalism and economic constitutionalism are four varieties of constitutionalism. But there are not adequate provisions regarding such constitutionalism. Although, some frameworks and attributes of constitutionalism have been included in the constitution.

Written constitution, supremacy of constitution, sovereignty and state power vested in the people, protection of social, political, economical, cultural rights as all generations of human rights, guarantee of fundamental rights, judicial review and judicial independence, checks and balance, limited government, division 
of powers, pluralism, periodical elections, autonomous media, civil society and good governance are some of the attributes of constitutionalism assimilated in the constitution of Nepal.

\section{Good governance under the Constitution}

Good governance is nothing but specialization of governance system. It, on the other hand is best form of governance where all the components of democracy have been implemented properly in the legal framework. So it can be said that good governance is the governance operated on the basis of rule of law. No one can be against of law, above the law and outside the law in the good governance system. All rulers and ruled are surrounded by law and law everywhere in good governance system. Participatory democracy is the bottom line of good governance system. However, the attributes of good governance are consolidated in the constitution of Nepal.

Rule of law: the basic assumption of rule of law is that peoples are ruled by law not by order or anything else. Operation of governance system under the framework of law and full protection of all sorts of rights by independent judiciary are the basic features of rule of law. There are various provisions regarding rule of law in the constitution of Nepal. Components of democratic system including civil liberties, fundamental rights, human rights, independent, impartial and competent judiciary, right to justice and concept of rule of law have been included in the constitution. Such as the provisions regarding constitution as the fundamental law, sovereign and state power vested in the people, provision of fundamental rights and its' remedy and independent judiciary are major provisions incorporated in the constitution under rule of law.

Transparency: Transparency is the process of making and implementing the decisions obeying the rules and regulations. The Constitution... Kapilmani Dahal - 46 - 
It is also a way of acquiring the information freely. Provision made about autonomous media, right to freedom of opinion and expression, right to communication are related to transparency.

Consensus orientation: Consensus orientation is the process of making and implementing the decisions and policies following participative model. Consensual politics is the back bone of consensus orientation. Understanding with all political life or structure is necessary for consensus orientation. Provisions relating to participative and inclusive democracy and pluralism are important provisions made for consensus orientation.

Participation: Participation is the organized efforts of people to choose their leaders and to influence the public policy. Equal opportunities to participate in decision making and Implementing process and policy making and implementing process is inevitable for participation. Competitive multiparty democracy and provision of building an egalitarian society founded on the proportional inclusive and participatory principles are the best examples of provisions made under participation. Provision relating to social justice is another provision made relating participation. There are other provisions which are also relating to participation

Equity and inclusiveness: Equity and inclusiveness are two important variables of good governance. Equity is near to equality but they are not same. Generally equality is ends and equity is means to meet that ends. Right to social justice is also related to equity and inclusiveness.

Responsiveness: Responsiveness is working pattern of ruler and representative. Ruler, representative or bureaucratic personnel should be responsible towards people. Service provider should provide the service within stipulated time and frame with legal framework. 
Accountability: All the governmental institutions should be accountable towards people. Service provider's acts also to be transparent. Ruler should always be listened the demands and interest of public. There is no provision except election to make representative responsible and accountable.

Effectiveness and efficiency: Effectiveness and efficiency are relating to allocations of values by governmental institutions. For effectiveness and efficiency, mobilization of natural as well as human resources should be managed properly. Distributive capabilities function of nation must be strong. All sorts of people should feel that government is working well for them. The provisions regarding division of powers in the constitution under different schedule made are relating to effectiveness and efficiency. Its practicability will be seeing later when it will be implemented in various levels. Federal, provincial and local structures and their concerning powers have been made for effectiveness and efficiency.

\section{Interrelationship of Constitutionalism and Good Governance}

Constitutionalism and good governance are two important components of democracy. They are inevitable for successful functioning of democracy. Not only this, the constitution can be said democratic or autocratic on the basis of provisions of constitutionalism and good governance made in the constitution. Constitutionalism is ends and good governance is out-put of constitutionalism. Constitutionalism guarantees the good governance. The constitution which has incorporated the elements of constitutionalism and they have been properly implemented then indicators of good governance can be seen in the practice. Good governance is concerning to participative and inclusive democratic system of governance. Good governance The Constitution... Kapilmani Dahal - 48 - 
is ideal which is difficult to achieve in its totality. It is impossible to achieve without constitutionalism. The elements of constitutionalism and good governance are interrelated and quite similar. Both are affected by each other. So it can be said that constitutionalism and good governance are not same but both are twin. We can see the constitutionalism there, where is good governance and we can see the good governance there, where is constitutionalism.

\section{Constitution: On the Touchstone}

The constitution of Nepal is in the course of implementation. Peoples have concern and anxiety towards its future. Average life of constitutions of Nepal has not been more than ten years. In this scenario, the question may not be strange that how long it will be lasted. Political instability has made the house of permanent instability in Nepal. The beginning scenario of forms of constitution's implementation is not fully satisfactory. The trend of implementing the constitution according to owns own interest is developing day by day. There are various challenges making the constitution success in the practice. Until and unless the constitution becomes success in the practicability, no one can feel the constitutionalism and good governance.

The constitution is silent on various elements of constitutionalism and good governance. There are various difficulties and challanges making the constitution successful and stable. This constitution is also encircling by various challenges. It will not be long lasting if political parties do not make consensus on democratic values and virtues. There are various possibilities but on its proportionate, there are more challenges also so, to make it success civic political culture must be developed. Civil society must be united impartially and Civics' participation must be increased rapidly. Constitutionalism and good governance 
are essence of democracy if they can't be met then democracy will be again dream for people for ever. So be unite to meet these essential elements of democracy then we can feel and live with the constitutionalism and good governance.

\section{Conclusion}

Nepal is such a country which has exercised various models of constitution in the short period of time. Previous constitutions were also adopted some attributes of good governance and constitutionalism but they were failed to adopt in practicability. Peoples become happy living under democratic governance system but for it, democratic governance should provide good governance and constitutionalism. Average life of constitutions of Nepal has not been more than ten years. The constitution which can't maintain political stability, can't also maintain constitutionalism and good governance. Now, the governance system of Nepal is operating on the ground of constitution of Nepal (2072). The constitution has adopted some attributes of constitutionalism and good governance. But they are not adequate for providing constitutionalism and good governance. With the inadequate provision about constitutionalism and good governance, there are various challenges for operating them in the practice also.

Constitution is the fundamental law of the land. All the provisions needed for the regulation of governance system can't be mention in the constitution. Major provisions which are thought to be guidelines for regulation of governance system, includes in the constitution. Good governance and constitutionalism which are mirror of democracy, puts important places for analyze life and value of constitution and governance system. The provisions made about these factors have been already mentioned. However, the constitution of Nepal is progressive 
and its proper implementation is inevitable. When it will be felt further provisions to be included in the constitution in the course of implementation then they can be included in the constitution on the consent of political energies.

Good governance and constitutionalism are very important and interrelated elements of democracy. Both are correlated and one becomes valueless in the absence of another. Constitutionalism paves the way for good governance. Constitutionalism and good governance are most essential elements among the elements of the democracy. so they are thought the essence of democracy. Good governance and constitutionalism are not same but both are twin. Democracy can't go ahead without proper implementation of these essential elements. So these are not only the essential elements of democracy but also the foundation stone or essence of democracy so, all the democratic superstructures can be built upon them. The Constitution of Nepal will be also evaluated on the touch-stone of these constitutionalism and good governance.

\section{References}

Dahal, Ramkumar (1999). Prospects of Good Governance, Kathmandu: FES. Dahal, Kapilmani (2072). "Role, of Communication in Good Governance Administration" Pragyamanch, vol 13 PN Campus Pokhara: TUTA. Diecy, A.V (1948). Law of Constitution, London: George Allen and Unwin. FES, (2007). Hand Outs on Democracy: Kathmandu.

Friederich, Karl J. (1994). Constitutional Government and Democracy, Calcutta: Oxford and IBH.

Government of Nepal, NLBC (2047). Constitution of Kingdom of Nepal 2047. Government of Nepal, NLBC (2063). Interim Constitution of Nepal 2063. Government of Nepal, NLBC (2072). Constitution of Nepal.

Johari, J.C. (1998). Comparative Politics, New Delhi: Sterling Publishers.

Strong, C.F (1966). Modern Political Constitutions, London: Sidgwick and Jaction, ELBS.

Wheare, K.C. (1956). Modern Constitutions, London: Oxford. 